\title{
УДК:633/635.002.33; 676.034, 635.21; 631.811
}

DOI: $10.37128 / 2707-5826-2020-19$

\section{УДОСКОНАЛЕННЯ ТЕХНОЛОГІЧНИХ ПРИЙОМІВ ВИРОЩУВАННЯ НАСІННЕВОЇ КАРТОПЛІ}

О.В. МАЗУР, канд. с.-г. наук, доиент

Г.В. МИРОНОВА, аспірантка

Р.В. СТАШЕВСЬКИЙ, аспірант

Вінницький національний аграрний університет

У статті приводяться результати досліджень впливу удобрення, маси садивних бульб та сортових особливостей на тривалість фенологічних фаз сортів картоплі різних груп стиглості. Найменша тривалість фенологічних фаз спостерігалася на контрольному варіанті досліду. У сорту Лаперла сходи з'являлися на 31-32 добу залежно від маси садивних бульб, у сорту Гранада на 33-34 добу, а у сорту Мемфіс - на 35-36 добу. Тобто, спостерігається загальне подовження періоду з'явлення сходів залежно від групи стиглості картоплі. Фаза бутонізащії раніме наступала у сорту Лаперла -на 48-49 добу, дещо пізніше у сорту Гранада - на 53-54 добу і ще пізніме у сорту Мемфіс - на 56-57 добу. Аналогічна тенденція спостерігалася $і$ у фази цвітіння, яка найшвидше наступала у ранньостиглого сорту Лаперла - на 65-66 добу, дещо пізніше у сорту Гранада - на 69-70 добу і найдовще у сорту Мемфіс - на 74-75 добу.

За збільшення внесення добрив локально дозою $N_{30} P_{30} K_{30}$ на фоні внесення $40 \mathrm{~m} / 2 а$ напівперепрілого гною під попередник - пшеницю озиму та Калімагнезія $K_{56} \mathrm{Mg}_{16} \mathrm{~S}_{30}$ i суперфосфату простого $P_{30}$ під основний обробіток картоплі та було проведено підживлення по сходах картоплі дозою $N_{30}$ (локально) спостерігалося подовження настання фенологічних фаз росту й розвитку. Так у сорту Лаперла сходи з'являлись на 38-39 добу, у сорту Гранада на 38 i 39 добу, а у сорту Мемфіс на 41 і 42 добу. Настання фази бутонізаиії на иьвому варіанті досліду у сорту Лаперла спостерігалося на 54-55 добу, у сорту Гранада на 58-59 добу, а у сорту Мемфіс на 61-62 добу. Настання фази ивітіння у сорту Лаперла відмічено на 72-73 добу, у сорту Гранада на 74-75 добу, а у сорту Мемфіс на 80 добу.

Ключові слова: тривалість фенологічних фаз, удобрення, маса садивних бульб, сортові особливості, Амофос, Нітроамофоска, напівперепрілий гній, підживлення, Калімагнезія.

Табл.1. Літ. 10.

Постановка проблеми. Використання сортових рослинних ресурсів $\epsilon$ однією 3 найважливіших ланок сільського господарства - основою економічного і соціального розвитку держави. Найефективнішим та економічно вигідним $\epsilon$ широке впровадження нових сортів та гібридів 3 генетично визначеним рівнем адаптування до умов грунтово-кліматичних зон їх вирощування [1, 2]. На сучасному етапі розвитку вчені всього світу висловлюють одностайну думку, що сорт відіграє визначну роль у зростанні 
обсягів виробництва продукції рослинництва, а також у підвищенні іï якості, конкурентоспроможності на внутрішньому і зовнішньому ринках [3].

Сорт відіграє роль основного засобу сільськогосподарського виробництва i виступає головним чинником його інтенсифікації. Лише за рахунок впровадження у виробництво нових сортів картоплі, за виключенням будь-яких інших додаткових витрат, можна збільшити врожайність бульб на 25-30\% i більше [4].

Аналіз останніх результатів досліджень. Картопля - надточний індикатор рівня добробуту українців, адже у період економії багато українців свої харчові вподобання спрямовують саме у цей сектор ринку. Дефіцит виконання науково обгрунтованої норми споживання складає: м'яса та м'ясопродуктів - 32,4\%, молока та молочних продуктів - 41,9\%, риби та рибопродуктів - 27\%, фруктів і ягід - 37,4\%. Тобто, в умовах «білкової недостатності» картопля поряд 3 овочевими культурами $\epsilon$ свого роду «страховим полісом» життя. Відомо, що вживання 300 г картоплі забезпечує отримання людиною майже повної норми вітаміну С, близько 50\% калію, 15\% заліза, 10\% фосфору, 3\% кальцію та 240 ккал [5].

Ефективним шляхом підвищення продуктивності галузі картоплярства $є$ введення у практику сільськогосподарського виробництва високоврожайних сортів, біологічні особливості яких найбільше відповідають грунтовокліматичним умовам вирощування [6]. Для створення таких сортів необхідно відбір селекційного матеріалу та його оцінку проводити саме в тих умовах, для яких ведеться селекція. Суттєве значення при цьому має не лише створення таких сортів, але й відповідне їх насінництво, яке постійно забезпечує виробництво високоякісним насіннєвим матеріалом, значно продовжуючи життя будь-якого сорту [7]. У зв’язку з різким скороченням використання добрив, а також їхньою високою вартістю, сорти та насіння нині є основними засобами отримання стабільно високих урожаїв. Вирощування високопродуктивних інтенсивного типу сортів, здатних максимально використовувати внесені добрива і умови високого агрофону, різко підвищує економічну ефективність застосування мінеральних добрив, i, цим самим, прискорить окупність витрат, є доступним i дешевим способом збільшення виробництва сільськогосподарських культур у цілому і картоплі зокрема [8, 9].

Мета досліджень - встановити тривалість фенологічних фаз сортів картоплі залежно від удобрення, маси садивних бульб та сортових особливостей.

Методика проведення досліджень. Трифакторний польовий дослід закладали за такою схемою: Фактор $A$ - сорти: Лаперла - ранній, Гранада середньоранній, Мемфіс - середньостиглий. Фактор $Б$ - фон живлення і спосіб внесення мінеральних добрив. Під попередник (пшениця озима) вносили напівперепрілий гній - 40 т/га. Калімагнезія $\left(\mathrm{K}_{28} \mathrm{Mg}_{8} \mathrm{~S}_{15}\right)$ та суперфосфат простий $\left(\mathrm{P}_{20}\right)$ вносили під основний обробіток картоплі. Під час садіння 
вносили в рядки або передпосівну культивацію нітроамофоску $\left(\mathrm{N}_{16} \mathrm{P}_{16} \mathrm{~K}_{16}\right)$ i аміачну селітру $\left(\mathrm{N}_{34}\right)-$ у підживлення по сходах картоплі. Фактор $B$ - маса садивних бульб: від 25 до 50 грам; від 51 до 80 грам; від 81 до 100 грам.

Фенологічні спостереження: візуально відмічали фази сходів, бутонізації, цвітіння і відмирання бадилля (за методикою проведення експертизи сортів рослин картоплі та груп овочевих, баштанних, пряно-смакових, Український інститут експертизи сортів рослин Міністерства аграрної політики та продовольства України, 2017 р.) [10].

Результати досліджень. За результатами наших досліджень тривалість фенологічних фаз сортів картоплі залежала від сортових особливостей, удобрення та маси садивних бульб. Найменша тривалість фенологічних фаз спостерігалася на контрольному варіанті досліду. У сорту Лаперла сходи 3’являлися на 31-32 добу залежно від маси садивних бульб, у сорту Гранада на 33-34 добу, а у сорту Мемфіс - на 35-36 добу. Тобто, спостерігається загальне подовження періоду з'явлення сходів залежно від групи стиглості картоплі. Фаза бутонізації раніше наступала у сорту Лаперла -на 48-49 добу, дещо пізніше у сорту Гранада - на 53-54 добу і ще пізніше у сорту Мемфіс - на 56-57 добу. Аналогічна тенденція спостерігалася i у фази цвітіння, яка найшвидше наступала у ранньостиглого сорту Лаперла - на 65-66 добу, дещо пізніше у сорту Гранада - на 69-70 добу і найдовше у сорту Мемфіс - на 74-75 добу.

Таблицяя 1

Тривалість фенофаз сортів картоплі в залежності від удобрення, маси садивних бульб та сортових особливостей

\begin{tabular}{|c|c|c|c|c|}
\hline \multirow{2}{*}{$\begin{array}{l}\text { Удобрення } \\
\text { фактор С }\end{array}$} & \multirow{2}{*}{$\begin{array}{c}\text { Маса садивних } \\
\text { бульб, г }\end{array}$} & \multicolumn{3}{|c|}{ Фенологічна фаза } \\
\hline & & Сходи & Бутонізація & Цвітіння \\
\hline 1 & 2 & 3 & 4 & 5 \\
\hline \multicolumn{5}{|c|}{ Лаперла } \\
\hline \multirow{3}{*}{ Без добрив (к) } & $25-50$ & 31 & 48 & 65 \\
\hline & $51-80$ & 31 & 48 & 66 \\
\hline & $81-100$ & 32 & 49 & 66 \\
\hline \multirow{3}{*}{$\begin{array}{l}40 \\
\text { напівперепрілого гною } \\
\text { під } \quad \text { попередник } \\
\mathrm{K}_{56} \mathrm{Mg}_{16} \mathrm{~S}_{30}+\mathrm{P}_{30} \text { (фон) }\end{array}$} & $25-50$ & 34 & 50 & 68 \\
\hline & $51-80$ & 34 & 50 & 69 \\
\hline & $81-100$ & 35 & 51 & 69 \\
\hline \multirow{3}{*}{$\begin{array}{l}\text { Фон }+\mathrm{N}_{30} \mathrm{P}_{30} \mathrm{~K}_{30} \\
\text { (локально) }\end{array}$} & $25-50$ & 36 & 52 & 70 \\
\hline & $51-80$ & 37 & 52 & 70 \\
\hline & $81-100$ & 37 & 53 & 71 \\
\hline \multirow{3}{*}{$\begin{array}{l}\text { Фон + N30Р } 30 \mathrm{~K}_{30} \\
\text { (локально) }+\mathrm{N}_{30}\end{array}$} & $25-50$ & 38 & 54 & 72 \\
\hline & $51-80$ & 38 & 54 & 72 \\
\hline & $81-100$ & 39 & 55 & 73 \\
\hline \multirow{3}{*}{$\begin{array}{l}\text { Фон }+\mathrm{N}_{45} \mathrm{P}_{45} \mathrm{~K}_{45} \\
\left(\text { врозкид) }+\mathrm{N}_{15}\right.\end{array}$} & $25-50$ & 38 & 55 & 72 \\
\hline & $51-80$ & 39 & 56 & 73 \\
\hline & $81-100$ & 39 & 56 & 73 \\
\hline
\end{tabular}


ISSN 2707-5826 СІЛЬСБКЕ ГОСПОДАРСТВО Екологія та охорона

продовження табл.1

\begin{tabular}{|c|c|c|c|c|}
\hline 1 & 2 & 3 & 4 & 5 \\
\hline \multicolumn{5}{|c|}{ Гранада } \\
\hline \multirow{3}{*}{ Без добрив (к) } & $25-50$ & 33 & 53 & 69 \\
\hline & $51-80$ & 33 & 54 & 69 \\
\hline & $81-100$ & 34 & 54 & 70 \\
\hline \multirow{3}{*}{$\begin{array}{l}40 \\
\text { напівперепрілого гною } \\
\text { під } \quad \text { попередник } \\
\mathrm{K}_{56} \mathrm{Mg}_{16} \mathrm{~S}_{30}+\mathrm{P}_{30} \text { (фон) }\end{array}$} & $25-50$ & 35 & 55 & 71 \\
\hline & $51-80$ & 35 & 55 & 72 \\
\hline & $81-100$ & 36 & 55 & 72 \\
\hline \multirow{3}{*}{$\begin{array}{l}\text { Фон }+\mathrm{N}_{30} \mathrm{P}_{30} \mathrm{~K}_{30} \\
\text { (локально) }\end{array}$} & $25-50$ & 36 & 56 & 73 \\
\hline & $51-80$ & 36 & 56 & 73 \\
\hline & $81-100$ & 37 & 57 & 73 \\
\hline \multirow{3}{*}{$\begin{array}{l}\text { Фон + N30Р30К } 30 \\
\text { (локально) }+\mathrm{N}_{30}\end{array}$} & $25-50$ & 38 & 58 & 74 \\
\hline & $51-80$ & 39 & 58 & 74 \\
\hline & $81-100$ & 39 & 59 & 75 \\
\hline \multirow{3}{*}{$\begin{array}{l}\Phi о н+\mathrm{N}_{45} \mathrm{P}_{45} \mathrm{~K}_{45} \\
\text { (врозкид) }+\mathrm{N}_{15}\end{array}$} & $25-50$ & 39 & 58 & 74 \\
\hline & $51-80$ & 39 & 58 & 75 \\
\hline & $81-100$ & 39 & 59 & 75 \\
\hline \multicolumn{5}{|c|}{ Мемфіс } \\
\hline \multirow{3}{*}{ Без добрив (к) } & $25-50$ & 35 & 56 & 74 \\
\hline & $51-80$ & 35 & 56 & 74 \\
\hline & $81-100$ & 36 & 57 & 75 \\
\hline \multirow{3}{*}{$\begin{array}{l}40 \\
\text { напівперепрілого гною } \\
\text { під } \quad \text { попередник } \\
\mathrm{K}_{56} \mathrm{Mg}_{16} \mathrm{~S}_{30}+\mathrm{P}_{30} \text { (фон) }\end{array}$} & $25-50$ & 37 & 57 & 76 \\
\hline & $51-80$ & 37 & 57 & 76 \\
\hline & $81-100$ & 38 & 58 & 77 \\
\hline \multirow{3}{*}{$\begin{array}{l}\text { Фон }+\mathrm{N}_{30} \mathrm{P}_{30} \mathrm{~K}_{30} \\
\text { (локально) }\end{array}$} & $25-50$ & 39 & 59 & 78 \\
\hline & $51-80$ & 39 & 59 & 78 \\
\hline & $81-100$ & 40 & 60 & 79 \\
\hline \multirow{3}{*}{$\begin{array}{l}\text { Фон + N30Р30К } 30 \\
\text { (локально) }+\mathrm{N}_{30}\end{array}$} & $25-50$ & 41 & 61 & 80 \\
\hline & $51-80$ & 41 & 61 & 80 \\
\hline & $81-100$ & 42 & 62 & 80 \\
\hline \multirow{3}{*}{$\begin{array}{l}\text { Фон }+\mathrm{N}_{45} \mathrm{P}_{45} \mathrm{~K}_{45} \\
\text { (врозкид) }+\mathrm{N}_{15}\end{array}$} & $25-50$ & 41 & 61 & 79 \\
\hline & $51-80$ & 42 & 61 & 80 \\
\hline & $81-100$ & 42 & 62 & 80 \\
\hline
\end{tabular}


Проте, тривалість міжфазних періодів росту і розвитку рослин картоплі змінювалася більш суттєво від фону живлення, способу внесення добрив та маси садивних бульб. Спостерігається залежність подовження настання фенологічних фаз росту й розвитку за внесення 40 т/га напівперепрілого гною під попередник - пшеницю озиму, калімагнезія $\mathrm{K}_{56} \mathrm{Mg}_{16} \mathrm{~S}_{30}$ та суперфосфату простого $\left(\mathrm{P}_{30}\right)$ під основний обробіток картоплі. Так у сорту Лаперла сходи з'явилися на 34-35 добу, а у середньораннього сорту Гранада на 35-36 добу, у середньостиглого сорту Мемфіс на 37-38 добу. Це стосується і термінів настання бутонізації у цих сортів картоплі різної групи стиглості. Так у сорту Лаперла фаза бутонізації наступала на 50-51 добу, у сорту Гранада на 55-56 добу, а у сорту Мемфіс на 57-58 добу.

Фаза цвітіння наставала на цьому варіанті досліду швидше у ранньостиглого сорту Лаперла на 68 - 69 добу, дещо пізніше у сорту Гранада на 71-72 добу і найпізніше у сорту Мемфіс на 76-77 добу.

Крім того, подовження настання фенологічних фаз росту й розвитку рослин картоплі спостерігалося на варіанті досліду, де на фоні внесення 40 т/га напівперепрілого гною під попередник - пшеницю озиму та під основний обробіток картоплі було внесено Калімагнезія $\mathrm{K}_{56} \mathrm{Mg}_{16} \mathrm{~S}_{30}$ та суперфосфат простий $\left(\mathrm{P}_{30}\right)$ i Нітроамофоску $\mathrm{N}_{30} \mathrm{P}_{30} \mathrm{~K}_{30}$ (локально). При цьому сходи з'являлися у сорту Лаперла на 36-37 добу, у сорту Гранада - на 36-37 добу, а у сорту Мемфіс на 39-40 добу. На цьому ж варіанті досліду фаза бутонізації у сорту Лаперла наступала на 52-53 добу, у сорту Гранада - на 56-57 добу, а у сорту Мемфіс - на 59-60 добу. Фаза цвітіння наступала у сорту Лапарла - на 70-71 добу, у сорту Гранада - на 73 добу, а у сорту Мемфіс - на 78-79 добу.

За внесення добрив локально дозою $\mathrm{N}_{30} \mathrm{P}_{30} \mathrm{~K}_{30}$ на фоні внесення 40 т/га напівперепрілого гною під попередник - пшеницю озиму та Калімагнезія $\mathrm{K}_{56} \mathrm{Mg}_{16} \mathrm{~S}_{30}$ i суперфосфату простого $\left(\mathrm{P}_{30}\right)$ під основний обробіток картоплі $\mathrm{i}$ було проведено підживлення по сходах картоплі дозою $\mathrm{N}_{30}$ спостерігалося подовження настання фенологічних фаз росту й розвитку. Так у сорту Лаперла сходи з'являлись на 38-39 добу, у сорту Гранада на 38 і 39 добу, а у сорту Мемфіс на 41 і 42 добу. Настання фази бутонізації на цьому варіанті досліду у сорту Лаперла спостерігалося на 54-55 добу, у сорту Гранада на 58-59 добу, а у сорту Мемфіс на 61-62 добу. Настання фази цвітіння у сорту Лаперла відмічено на 72-73 добу, у сорту Гранада на 74-75 добу, а у сорту Мемфіс на 80 добу.

Подібний термін настання фенологічних фаз було отримано на варіанті досліду, де вносили мінеральні добрива врозкид дозою $\mathrm{N}_{45} \mathrm{P}_{45} \mathrm{~K}_{45}$ i було проведено підживлення по сходах картоплі дозою $\mathrm{N}_{15}$ на фоні внесення 40 т/га напівперепрілого гною під попередник - пшеницю озиму та Калімагнезія $\mathrm{K}_{56} \mathrm{Mg}_{16} \mathrm{~S}_{30}$ i суперфосфату простого $\left(\mathrm{P}_{30}\right)$. Так настання сходів у сорту Лаперла на цьому варіанті досліду відмічено на 38 і 39 добу, у сорту Гранада на 39 добу, а у сорту Мемфіс на 41-42 добу. Настання фази бутонізації на цьому варіанті досліду відмічено у сорту Лаперла на 55-56 добу, у сорту Гранада на 59-60 добу 
і у сорту Мемфіс на 61-62 добу. Настання фази цвітіння відмічено у сорту Лаперла на 72-73 добу, у сорту Гранада на 74-75 добу, а у сорту Мемфіс на 7980 добу.

Тобто терміни настання фенологічних фаз за 4 і 5 варіантів досліду не значно відрізнялися, це підтверджується настанням фаз сходів, бутонізації i цвітіння на цих варіантах дослідів. Отже, із збільшенням доз внесених добрив терміни настання фенологічних фаз будуть затримуватися у сортів картоплі різних груп стиглості, окрім цього на терміни настання фенологічних фаз буде впливати маса садивних бульб із збільшенням якої настання фенологічних фаз буде пізніше.

Висновки і перспективи подальших досліджень. Найменша тривалість фенологічних фаз спостерігалася на контрольному варіанті досліду. У сорту Лаперла сходи з'являлися на 31-32 добу залежно від маси садивних бульб, у сорту Гранада - на 33-34 добу, а у сорту Мемфіс - на 35-36 добу. Тобто, спостерігається загальне подовження періоду з'явлення сходів залежно від групи стиглості картоплі. Фаза бутонізації раніше наступала у сорту Лаперла на 48-49 добу, дещо пізніше у сорту Гранада - на 53-54 добу і ще пізніше у сорту Мемфіс - на 56-57 добу. Аналогічна тенденція спостерігалася і у фази цвітіння, яка найшвидше наступала у ранньостиглого сорту Лаперла - на 65-66 добу, дещо пізніше у сорту Гранада - на 69-70 добу і найдовше у сорту Мемфіс - на 74-75 добу.

За збільшення внесення добрив локально дозою $\mathrm{N}_{30} \mathrm{P}_{30} \mathrm{~K}_{30}$ на фоні внесення 40 т/га напівперепрілого гною під попередник - пшеницю озиму та Калімагнезія $\mathrm{K}_{56} \mathrm{Mg}_{16} \mathrm{~S}_{30}$ i i суперфосфату простого $\left(\mathrm{P}_{30}\right)$ під основний обробіток картоплі і проведено підживлення по сходах картоплі дозою $\mathrm{N}_{30}$ локально спостерігалося подовження настання фенологічних фаз росту й розвитку. Так у сорту Лаперла сходи з'являлись на 38-39 добу, у сорту Гранада на 38 і 39 добу, а у сорту Мемфіс на 41 і 42 добу. Настання фази бутонізації на цьому варіанті досліду у сорту Лаперла спостерігалося на 54-55 добу, у сорту Гранада на 58-59 добу, а у сорту Мемфіс на 61-62 добу. Настання фази цвітіння у сорту Лаперла відмічено на 72-73 добу, у сорту Гранада на 74-75 добу, а у сорту Мемфіс на 80 добу.

\section{Список використаної літератури}

1. Захарчук О. В. Сорт як інноваційна основа розвитку рослинництва. Агроінком. 2009. № 5-8. С. 17-22.

2. Шелепов В. В. Сорт і його значення в підвищенні врожайності. Сортовивчення та охорона прав на сорти рослин. К.: Алефа, 2006. 140 с.

3. Завірюха П. Д. Селекція картоплі у Львівському НАУ: результати i перспективи. Інноваційний розвиток АПК: проблеми та їх вирішення: матер. міжнар. наук.-практ. конф., присвяченої пам'яті декана агрономічного факультету М. Ф. Рибака (м. Житомир, 19-20 листопада 2015 р.). Житомир: 
Вид-во «Житомирський національний агроекологічний університет», 2015. С. 45-50.

4. Осипчук А. А. Становлення селекції картоплі в Україні. Генетика i селекція в Україні на межі тисячоліть. К., 2001. Т. 3. С. 336-338.

5. Рудь В. П., Муравйова О. В., Сидора В. В. Проблеми розвитку ринку картоплі в Україні. Овочівницттво і баштанництво. 2015. Вип. 61. С. 193-199.

6. Бугаєва I. П., Черниченко О. О., Черниченко I. I. Сорти картоплі різних груп стиглості, придатні для вирощування в умовах півдня двоврожайною культурою. Таврійський науковий вісник. 2007. Вип. 50. С. 59-63.

7. Букасов С. М., Камераз А. Я. Селекция и семеноводство картофеля. Л., 1972. $359 \mathrm{c}$.

8. White P. J. et al. Relationships between yield and mineral concentrations in potato tubers. HortScience. 2009. Vol. 44. № 1. P. 6-11.

9. Остапчук М.О., Поліщук I.С., Мазур О.В., Максімов А.М. Використання біопрепаратів - перспективний напрямок вдосконалення агротехнологій. Збірник наукових праџь ВНАУ. Сільське господарство та лісівнищтво. 2015. № 2. C. 5-17.

10. Методика проведення експертизи сортів рослин картоплі та груп овочевих, баштанних, пряно-смакових на придатність до поширення в Україні (ПСП) / За ред. Ткачик С. О. Вінниця: ФОП Корзун Д. Ю., 2017. С. 6-7.

\section{Список використаної літератури у транслітерації}

1.Zaxarchuk O. V. (2009). Sort yak innovacijna osnova rozvy'tku rosly`nny`cztva [Variety as an innovative basis for crop development]. Agroinkom Agroincom. № 5-8. 17-22.

2.Shelepov V. V. (2006) Sort i jogo znachennya v pidvy`shhenni vrozhajnosti. Sortovy`vchennya ta oxorona prav na sorty` rosly`n [Variety and its importance in increasing yields. Variety research and protection of plant variety rights]. K.: Alefa.

3.Zaviryuxa P. D. (2015). Selekciya kartopli u L`vivs`komu NAU: rezul`taty` i perspekty`vy`. Innovacijny`j rozvy`tok APK: problemy` ta yix vy`rishennya:mater. mizhnar. nauk.-prakt. konf., pry`svyachenoyi pam'yati dekana agronomichnogo fakul'tetu M. F. Ry`baka [Potato breeding in Lviv NAU: results and prospects. Innovative development of agro-industrial complex: problems and their solutions: mater. international scientific-practical conference dedicated to the memory of the Dean of the Faculty of Agronomy MF Rybak]. (m. Zhy`tomy`r, 19-20 ly`stopada 2015 r.). Zhy`tomy`r: Vy`d-vo «Zhy`tomy`rs`ky`j nacional`ny`j agroekologichny`j universy`tet», 45-50.

4.Osy`pchuk A. A. (2001). Stanovlennya selekciyi kartopli v Ukrayini. Genety`ka i selekciya v Ukrayini na mezhi ty`syacholit`[Formation of potato breeding in Ukraine. Genetics and selection in Ukraine at the turn of the millennium] K., Vols. 3. 336-338.

5.Rud` V. P., Muravjova O. V., Sy`dora V. V. (2015). Problemy` rozvy`tku ry`nku kartopli v Ukrayini [Problems of potato market development in Ukraine]. 
Ovochivny`cztvo i bashtanny`cztvo - Vegetable and melon growing. Issue 61. 193199.

6.Bugayeva I. P., Cherny`chenko O. O., Cherny`chenko I. I. (2007). Sorty` kartopli rizny`x grup sty`glosti, pry`datni dlya vy`roshhuvannya v umovax pivdnya dvovrozhajnoyu kul turoyu [Potato varieties of different maturity groups, suitable for growing in the south by two-crop]. Tavrijs 'ky`j naukovy`j visny`k - Taurian Scientific Bulletin. Xerson, Issue 50. 59-63.

7.Bukasov S. M., Kameraz A. Ya. (1972). Selekcy`ya y` semenovodstvo kartofelya [Selection and seed production of potatoes]. L.

8.White P. J. et al. (2009). Relationships between yield and mineral concentrations in potato tubers [Relationships between yield and mineral concentrations in potato tubers]. HortScience-HortScience. Vols. 44. 1. 6-11.

9.Ostapchuk M.O., Polishhuk I.S., Mazur O.V., Maksimov A.M. (2015). Vy`kory`stannya biopreparativ - perspekty`vny`j napryamok vdoskonalennya agrotexnologij [The use of biological products is a promising area for improving agricultural technologies]. Zbirny`k naukovy`x pracz`VNAU. Sil`s `ke gospodarstvo ta lisivny'czvo - Collection of scientific works of VNAU. Agriculture and forestryVinny`cya. № 2. 5-17.

10.Metody`ka provedennya eksperty`zy` sortiv rosly`n kartopli ta grup ovochevy`x, bashtanny`x, pryano-smakovy`x na pry`datnist` do poshy`rennya $\mathrm{v}$ Ukrayini (PSP) [Methods of examination of potato plant varieties and groups of vegetables, melons, spices for suitability for distribution in Ukraine (PSP)] (2017). I Za red. Tkachy`k S. O. Vinny`cya: FOP Korzun D. Yu. 6-7.

\section{АННОТАЦИЯ \\ СОВЕРШЕНСТВОВАНИЕ ТЕХНОЛОГИЧЕСКИХ ПРИЕМОВ ВЫРАЩИВАНИЯ СЕМЕННОГО КАРТОФЕЛЯ}

В статье приводятся результаты исследований влияния удобрения, массы посадочных клубней и сортовых особенностей на продолжительность фенологических фаз сортов картофеля различных групп спелости.

Наименьшая продолжительность фенологических фаз наблюдалась на контрольном варианте опыта. У сорта Ла-Перл лестницы появлялись на 31-32 сутки в зависимости от массы посадочных клубней, у сорта Гранада - на 33-34 сутки, а у сорта Мемфис - на 35-36 сутки. То есть, наблюдается общее удлинение периода появления всходов в зависимости от группы спелости картофеля. Фаза бутонизации ранее наступала у сорта Ла-Перл-на 48-49 сутки, несколько позже в сорта Гранада - на 53-54 сутки и еще позже у сорта Мемфис - на 56-57 сутки. Аналогичная тенденция наблюдалась и в фазе ияетения, которая быстро наступала в раннеспелого сорта Ла-Перл - на 65-66 сутки, несколько позже в сорта Гранада - на 69-70 сутки и дольше у сорта Мемфис - на 74-75 сутки. При увеличении внесения удобрений локально дозой N45P45K45 на фоне внесения $40 \mathrm{~m} /$ га полуперепревщего навоза под предмественник - пшенииу озимую и Калимагнезия К56Mg16S30 под основную обработку картофеля и были внесены Аммофос N10P46

(вразброс) и проведена подкормка по лестнице картофеля дозой N17 наблюдалось удлинение наступления фенологических фаз роста и развития. Так у сорта Ла-Перл лестниць появлялись на 38-39 сутки, у сорта Гранада на 38 и 39 сутки, а у сорта Мемфис на 41 и 42 
сутки. Наступление фазы бутонизации на этом варианте опыта у сорта Ла-Перл наблюдалось на 54-55 сутки, у сорта Гранада на 58-59 сутки, а у сорта Мемфис на 61-62 сутки. Наступление фазы ияветения у сорта Ла-Перл отмечено на 72-73 сутки, у сорта Гранада на 74-75 сутки, а у сорта Мемфис на 80 сутки.

Ключевые слова: продолжительность фенологических фаз, удобрения, масса посадочных клубней, сортовые особенности, Аммофос, Нитроаммофоска, полуперепревщий навоз, подкормка, Калимагнезия.

Табл.1. Лит. 10.

\section{ANNOTATION \\ IMPROVEMENT OF TECHNOLOGICAL METHODS OF SEED POTATO GROWING}

The article presents the results of studies of the influence of fertilizer, weight of planting tubers and varietal characteristics on the duration of phenological phases of potato varieties of different ripeness groups. In the Laperla variety, seedlings appeared for 31-32 days, depending on the weight of the tubers, in the Granada variety, for 33-34 days, and in the Memphis variety, for 3536 days. That is, there is a general prolongation of the period of emergence of seedlings depending on the group of ripeness of potatoes. The budding phase used to occur in the Laperla variety - on 48-49 days, a little later in the Granada variety - on 53-54 days and even later in the Memphis variety - on 56-57 days. A similar trend was observed in the flowering phase, which occurred most rapidly in the early-maturing variety Laperla - 65-66 days, a little later in the variety Granada 69-70 days and the longest in the variety Memphis - 74-75 days.

Due to the increase in topical fertilization with the dose of N45P45K45 against the background of $40 \mathrm{t} / \mathrm{ha}$ of semi-roasted manure under the predecessor - winter wheat and Kalimagnesia K56Mg16S30 under the main tillage of potatoes and Amophos N10P46 prolongation of the onset of phenological phases of growth and development. Thus, in the Laperla variety the seedlings appeared on days 38-39, in the Granada variety on the 38th and 39th days, and in the Memphis variety on the 41st and 42nd days. The onset of the budding phase in this variant of the experiment in the variety Laperla was observed for 54-55 days, in the variety Granada for 58-59 days, and in the variety Memphis for 61-62 days. The onset of the flowering phase in the Laperla variety was observed for 72-73 days, in the Granada variety for 74-75 days, and in the Memphis variety for 80 days.

Key words: duration of phenological phases, fertilizers, weight of planting tubers, varietal features, Amophos, Nitroammophoska, half-roasted manure, fertilization, Kalimagnesia.

Tabl.1. Lit. 10.

\section{Інформація про авторів}

Мазур Олександр Васильович - кандидат сільськогосподарських наук, доцент кафедри рослинництва, селекції та біоенергетичних культур Вінницького національного аграрного університету (21008, м. Вінниця, вул. Сонячна, 3. e-mail: selection@vsau.vin.ua).

Миронова Ганна Володимирівна - аспірантка кафедри рослинництва, селекції та біоенергетичних культур Вінницького національного аграрного університету (21008, м. Вінниця, вул. Сонячна 3).

Сташевський Роман Володимирович - аспірант кафедри рослинництва, селекції та біоенергетичних культур Вінницького національного аграрного університету (21008, м. Вінниця, вул. Сонячна 3). 
Мазур Александр Васильевич - кандидат сельскохозяйственных наук, доцент кафедры растениеводства, селекции и биоэнергетических культур Винницкого национального аграрного университета (21008, г. Винница, ул. Солнечная, 3 e-mail: selection@vsau.vin.ua).

Миронова Анна Влодимировна - аспирантка кафедры растениеводства, селекции и биоэнергетических культур Винницкого национального аграрного университета (21008, г. Винница, ул. Солнечная 3).

Сташевский Роман Владимирович - аспирант кафедры растениеводства, селекции и биоэнергетических культур Винницкого национального аграрного университета (21008, г. Винница, ул. Солнечная 3).

Mazur Oleksandr Vasyliovych - Candidate of Agricultural Sciences, Associate Professor of the Department of Plant Production, Selection and Bioenergetic Cultures, Vinnytsia National Agrarian University (21008, Vinnytsia, Soniachna Str., 3, e-mail: selection@vsau.vin.ua).

Mironova G.V. - graduate student of the Department of Plant Breeding, Breeding and Bioenergy Crops of Vinnytsia National Agrarian University (21008, Vinnytsia, Soniachna Str. 3).

Stashevsky R.V. - Postgraduate student of the Department of Plant Breeding, Breeding and Bioenergy Crops of Vinnytsia National Agrarian University (21008, Vinnytsia, Soniachna Str. 3). 